Article

\title{
Assessing the Response of Diverse Sesame Genotypes to Waterlogging Durations at Different Plant Growth Stages
}

\author{
Mohammad Habibullah ${ }^{1,2}$, Shahnaz Sarkar ${ }^{1}$, Mohammad Mahbub Islam ${ }^{1}$, Kamal Uddin Ahmed ${ }^{1}$, \\ Md. Zillur Rahman ${ }^{3}$, Mohamed F. Awad ${ }^{4}\left(\mathbb{D}\right.$, Abdelaleim I. ElSayed ${ }^{5, *} \mathbb{D}$, Elsayed Mansour ${ }^{6, *(\mathbb{D}}$ \\ and Md. Sazzad Hossain ${ }^{3, * \mathbb{D}}$
}

Citation: Habibullah, M.; Sarkar, S.; Islam, M.M.; Ahmed, K.U.; Rahman, M.Z.; Awad, M.F. ElSayed, A.I.; Mansour, E.; Hossain, M.S. Assessing the Response of Diverse Sesame Genotypes to Waterlogging Durations at Different Plant Growth Stages. Plants 2021, 10, 2294. https://doi.org/10.3390/ plants10112294

Academic Editors: Rosalyn B. Angeles-Shim and Balram Marathi

Received: 15 August 2021

Accepted: 18 October 2021

Published: 25 October 2021

Publisher's Note: MDPI stays neutral with regard to jurisdictional claims in published maps and institutional affiliations.

Copyright: (c) 2021 by the authors. Licensee MDPI, Basel, Switzerland. This article is an open access article distributed under the terms and conditions of the Creative Commons Attribution (CC BY) license (https:// creativecommons.org/licenses/by/ $4.0 /)$.
1 Department of Agricultural Botany, Sher-e-Bangla Agricultural University, Sher-e-Bangla Nagar, Dhaka 1207, Bangladesh; habibagriculg@gmail.com (M.H.); shahnazsarkar2@hotmail.com (S.S.); mahbubislam_sau@yahoo.com (M.M.I.); kuahamed@yahoo.com (K.U.A.)

2 Syngenta Bangladesh Limited, Green Rowshan Ara Tower (5th \& 6th Floor), 55 Satmasjid Road, Dhanmondi, Dhaka 1205, Bangladesh

3 Department of Agronomy and Haor Agriculture, Sylhet Agricultural University, Sylhet 3100, Bangladesh; zillur.agronomy@sau.ac.bd

4 Department of Biology, College of Science, Taif University, P.O. Box 11099, Taif 21944, Saudi Arabia; m.fadl@tu.edu.sa

5 Department of Biochemistry, Faculty of Agriculture, Zagazig University, Zagazig 44511, Egypt

6 Department of Crop Science, Faculty of Agriculture, Zagazig University, Zagazig 44519, Egypt

* Correspondence: aelsayed@zu.edu.eg (A.I.E.); sayed_mansour_84@yahoo.es (E.M.); sazzadmh.aha@sau.ac.bd (M.S.H.)

\begin{abstract}
Sesame is sensitive to waterlogging, and its growth is devastatingly impacted under excess moisture conditions. Thus, waterlogging tolerance is crucial to alleviate yield constraints, particularly under expected climate change. In this study, 119 diverse sesame genotypes were screened for their tolerance to $12,24,48$, and $72 \mathrm{~h}$ of waterlogging relative to non-waterlogged conditions. All plants died under $72 \mathrm{~h}$ of waterlogging, while $13.45 \%, 31.93 \%$, and $45.38 \%$ of genotypes survived at 48,24 , and $12 \mathrm{~h}$, respectively. Based on the seedling parameters and waterlogging tolerance coefficients, genotypes BD-7008 and BD-6985 exhibited the highest tolerance to waterlogging, while BD-6996 and JP-01811 were the most sensitive ones. The responses of these four genotypes to waterlogged conditions were assessed at different plant growth stages-30, 40, and 50 days after sowing (DAS)—versus normal conditions. Waterlogging, particularly when it occurred within 30 DAS, destructively affected the physiological and morphological characteristics, which was reflected in the growth and yield attributes. Genotype BD-7008, followed by BD-6985, exhibited the highest chlorophyll and proline contents as well as enzymatic antioxidant activities, including superoxide dismutase (SOD), peroxidase (POD), and catalase (CAT). These biochemical and physiological adjustments ameliorated the adverse effects of waterlogging, resulting in higher yields for both genotypes. Conversely, JP-01811 presented the lowest chlorophyll and proline contents as well as enzymatic antioxidant activities, resulting in the poorest growth and seed yield.
\end{abstract}

Keywords: sesame; genotypes; waterlogging; tolerance; growth; yield; principal component analysis

\section{Introduction}

Sesame (Sesamum indicum L.) is one of the oldest and most essential oilseed crops worldwide [1]. Its total cultivated area is nearly 13 million hectares, which produce about 6.5 million tons annually [2]. Globally, it is utilized in several edible uses, cosmetics preparations, drugs, paints, perfumes, soaps, lubricants, fungicides, and insecticides [3]. Sesame is cultivated in different soil types, but it greatly thrives in well-drained fertile soils with a neutral $\mathrm{pH}$ [4]. However, it is commonly grown in rainfed conditions and is often exposed to flooded conditions [5]. As a result, sesame is tremendously sensitive to waterlogging and continuous heavy rains compared to other crops [1,6]. Even brief periods 
of excess moisture result in considerable reductions in seed yield [7]. Waterlogging causes a variety of morphological, physiological, and biochemical alterations that adversely affect plant growth, development, and production [8-10].

Waterlogging stress occurs when the soil pores become fully saturated, preventing normal air circulation in the rhizosphere $[8,11]$. With this switch from aerobic to anaerobic respiration, the reduction in $\mathrm{O}_{2}$ availability reduces the energy generated by the plant. In addition, oxygen deficiency (hypoxia) or its complete absence (anoxia) in the soil causes a reorganization of metabolic fluxes, resulting in an immediate energy crisis and plant death [12]. With a shortfall in oxygen availability, the processes that depend on oxygen, such as carbon assimilation and photosynthate utilization, are suppressed [13,14]. Moreover, oxygen depletion and rising carbon dioxide concentrations devastatingly impact root growth and disturb the functional relationships between roots and shoots [15-18]. Additionally, in the waterlogged soil, compounds such as ethylene, manganese, carbon dioxide, and iron concentrations may rise, causing chronic toxicity as well as anaerobic microbial metabolites, which may accumulate [19]. Furthermore, low-oxygen stress leads to increasing toxic reactive oxygen species (ROS), such as hydroxyl radical $\left({ }^{\bullet} \mathrm{OH}\right)$, singlet oxygen $\left({ }^{1} \mathrm{O}_{2}\right)$, hydrogen peroxide $\left(\mathrm{H}_{2} \mathrm{O}_{2}\right)$, and superoxide radical $\left(\mathrm{O}^{2 \bullet-}\right)$. Accumulation of ROS leads to lipid peroxidation, protein degradation, and enzyme inactivation. Furthermore, biomolecules, such as nucleic acids, and cellular structures, such as membranes, can be damaged by ROS production $[20,21]$.

Plants have a complex defense antioxidant system to mitigate the oxidative deteriorations caused by ROS [22-24]. The antioxidant system includes low molecular weight antioxidants, such as proline and antioxidant enzymes, which include ascorbate peroxidase (APX), catalase (CAT), superoxide dismutase (SOD), glutathione reductase (GR), and guaiacol peroxidase (GPX) [25-28]. Waterlogging tolerance has been related to the ability of the plants to scavenge ROS and reduce harmful effects, with considerable differences among the genotypes [29-32].

Waterlogging stress may worsen due to expected changes in the climate, which may increase the frequency of excess moisture and continuous heavy rains [33]. Consequently, developing tolerant genotypes is the most suitable and cost-effective approach to cope with this situation [34-36]. However, a deeper understanding of the underlying tolerant mechanism is necessary to improve waterlogging tolerance in sesame. Therefore, it is crucial to assess diverse sesame genotypes under waterlogging stress to identify tolerant accessions and investigate the tolerance mechanisms. Moreover, the duration of waterlogging and the occurrence of excess moisture during the growth stage have different impacts on physiological metabolism and, accordingly, plant growth and productivity [26,37]. Studies on the response of sesame genotypes under different durations of waterlogging at diverse growth stages are lacking. Hence, the current study was designed (i) to evaluate diverse sesame genotypes under various durations of waterlogging and identify valuable tolerant genetic resources; and (ii) investigate the response of sesame genotypes to waterlogged conditions at different plant growth stages and identify the critical stage that is most sensitive to waterlogging.

\section{Materials and Methods}

\subsection{Laboratory Experiment}

A total of 119 genotypes were assessed for their adaptive capacity under waterlogged conditions (Table 1). Seeds of different genotypes were obtained from the Plant Genetic Resource Center (PGRC), Bangladesh Agricultural Research Institute (BARI), Joydebpur, Gazipur, Bangladesh. First, 13 (4-4-4-1) healthy seeds of each genotype were placed in a Petri dish lined with moist filter paper. The seeds were left in an incubator (EYELA LTI-700, Japan) for three days under controlled conditions (temperature of $25 \pm 2{ }^{\circ} \mathrm{C}$; RH of $65-70 \%$ ) for uniform germination. After three days, the Petri dishes were transferred into a control growth room at a temperature of $25 \pm 2{ }^{\circ} \mathrm{C}$ with $60 \%$ relative humidity and 8 and $16 \mathrm{~h}$ of light and dark. Then, $10 \mathrm{~mL}$ of distilled water with a 1000-fold diluted Hyponex solution 
(Type: 5-10-5, Hyponex, Yodogawa-ku, Osaka, Japan) was applied to each Petri dish. After that, $5 \mathrm{~mL}$ of the Hyponex solution was added each day to every Petri dish to keep the seeds moist and compensate for evaporation losses. After five days, uniform seedlings were selected and divided into five groups. Then, five uniform seedlings were selected and treated for 12, 24, 48, and $72 \mathrm{~h}$ using $200 \mathrm{~mL}$ of distilled water to avoid oxygen exchange with the air (water stress), and a control group was treated with a standard tap water supply to keep the seeds moist. The experiment was laid out in a completely randomized design (CRD) with five treatments and replicated three times.

Table 1. List of the evaluated sesame genotypes.

\begin{tabular}{|c|c|c|c|c|c|c|c|}
\hline No. & Accession Name & No. & Accession Name & No. & Accession Name & No. & Accession Name \\
\hline 1 & BD-6971 & 31 & JP-14017 & 61 & KMR-100 & 91 & JP-5 \\
\hline 2 & BD-6960 & 32 & BD-7014 & 62 & BD-7004 & 92 & BD-6966 \\
\hline 3 & JP-01514 & 33 & BD-6987 & 63 & BD-6981 & 93 & BD-6995 \\
\hline 4 & BD-6979 & 34 & JP-35-2 & 64 & BD-6978 & 94 & AMA-102 \\
\hline 5 & BD-10167 & 35 & BD-6962 & 65 & JP-01411 & 95 & BD-7001 \\
\hline 6 & BARI-Til-3 & 36 & TT-152 & 66 & MTR-66 & 96 & JP-00515 \\
\hline 7 & BD-7015 & 37 & BD-7023 & 67 & BD-6984 & 97 & BD-7017 \\
\hline 8 & BD-6986 & 38 & BD-7006 & 68 & BD-7000 & 98 & KASI-22 \\
\hline 9 & BD-7027 & 39 & BD-6972 & 69 & AHM-150 & 99 & BD-7029 \\
\hline 10 & BD-6980 & 40 & BD-10166 & 70 & BD-6959 & 100 & BD-7013 \\
\hline 11 & BD-6990 & 41 & IAH-333 & 71 & JP-14004 & 101 & JP-160 \\
\hline 12 & BD-6964 & 42 & BD-7009 & 72 & AC-316 & 102 & BD-6999 \\
\hline 13 & BD-6992 & 43 & BD-6982 & 73 & BD-7026 & 103 & GP-5 \\
\hline 14 & JP-14013 & 44 & BD-6993 & 74 & BD-7018 & 104 & GP-21 \\
\hline 15 & BARI-Til-4 & 45 & BD-6983 & 75 & BD-6968 & 105 & GP-35-1 \\
\hline 16 & BD-6985 & 46 & BD-7022 & 76 & BD-6980 & 106 & GP-35-2 \\
\hline 17 & JP-02513 & 47 & JP-14016 & 77 & BD-6996 & 107 & GP-83-1 \\
\hline 18 & BD-7012 & 48 & JP-00411 & 78 & JP-01311 & 108 & GP-83-3 \\
\hline 19 & BD-6961 & 49 & TRMR-55 & 79 & BD-7003 & 109 & GP-160 \\
\hline 20 & AHI-12 & 50 & JP-01611-2 & 80 & BD-6991 & 110 & GP-181-1 \\
\hline 21 & BD-7019 & 51 & JP-01711 & 81 & BD-6998 & 111 & GP-254 \\
\hline 22 & JP-10311 & 52 & RISA-39 & 82 & JP-01811 & 112 & GP-694 \\
\hline 23 & BD-6974 & 53 & BD-10165 & 83 & KAI-112 & 113 & GP-964 \\
\hline 24 & NRI-13 & 54 & JP-03013 & 84 & BD-6994 & 114 & GP-212 \\
\hline 25 & BD-10164 & 55 & BD-7021 & 85 & BD-6989 & 115 & GP-00411 \\
\hline 26 & BD-7011 & 56 & MRI-31 & 86 & JP-83-3 & 116 & GP-515 \\
\hline 27 & JP-35-1 & 57 & BD-7008 & 87 & BD-7020 & 117 & GP-01311 \\
\hline 28 & BD-6988 & 58 & JP-14003 & 88 & NQR-37 & 118 & GP-01411 \\
\hline 29 & BD-7005 & 59 & BD-6970 & 89 & BD-7007 & 119 & GP1514 \\
\hline 30 & S. Local & 60 & BD-6997 & 90 & BD-7016 & & \\
\hline
\end{tabular}

The seedling lengths $(\mathrm{cm})$ and fresh weights $(\mathrm{g})$ were measured for each genotype under the control and waterlogged conditions after 8 days. In addition, the waterlogging tolerance coefficient (WTC) was recorded for each genotype in percentage using the following formula:

$$
\begin{gathered}
\text { WTC }(\text { weight })=\frac{\text { Seedling fresh weight under waterlogged conditions }}{\text { Seedling fresh weight under control conditions }} \times 100 \\
W T C(\text { length })=\frac{\text { Seedling length under waterlogged conditions }}{\text { Seedling length under control conditions }} \times 100
\end{gathered}
$$

Moreover, growth inhibition was estimated as a percentage relative to the length of the shoots and rootlets from the control (tap water). 


\subsection{Pot Experiment}

\subsubsection{Experimental Design and Treatments}

The experiment was conducted using a completely randomized design (CRD) with five replications at the Bangladesh Agricultural Research Institute (BARI), Joydebpur, Gazipur $\left(23^{\circ} 59^{\prime} \mathrm{N}, 90^{\circ} 24^{\prime} \mathrm{E}\right)$. Four genotypes were used in this experiment based on the obtained results of the preliminary laboratory experiment. The sesame genotypes used were divided into two tolerant (BD-7008 and BD-6985) and two sensitive (JP-01811 and BD-6996). Plastic pots that were $35 \mathrm{~cm}$ deep and $25 \mathrm{~cm}$ in diameter were filled with $10 \mathrm{~kg}$ of sandy loam soil mixed with coir pith compost (Table 2). Five seeds were sown in each pot, and after complete emergence, one plant was maintained per pot and the excess plants were thinned out. The genotypes were evaluated under waterlogged conditions at three different growth stages-30, 40, and 50 days after sowing (DAS) in comparison to the control (normal conditions, without waterlogging). The duration of waterlogging was $48 \mathrm{~h}$ and the water levels were maintained at $3 \mathrm{~cm}$ above the soil surface by replenishing frequently. After the treatment period, the water was drained out from the pots and the plants grew to maturity.

Table 2. Physico-chemical characterizations of the pot soil mixture used in the experiment.

\begin{tabular}{cccc}
\hline \multicolumn{2}{c}{ Physical Properties } & \multicolumn{2}{c}{ Chemical Properties } \\
\hline Soil Characteristics & Value & Soil Characteristics & Value \\
\hline Sand $(\%)$ & 17.60 & Soil $\mathrm{pH}$ & 5.59 \\
Silt $(\%)$ & 47.30 & Total N $(\%)$ & 0.14 \\
Clay $(\%)$ & 35.10 & Organic C $(\%)$ & 0.68 \\
Textual class & Silty clay loam & C:N ratio & 5.0 \\
Bulk density $\left(\mathrm{g} / \mathrm{cm}^{3}\right)$ & 1.40 & Available P (ppm) & 6.68 \\
Particle density $\left(\mathrm{g} / \mathrm{cm}^{3}\right)$ & 2.61 & Exchangeable K (meq $/ 100 \mathrm{~g})$ & 0.13 \\
Porosity $(\%)$ & 47.4 & Available Sulphur $(\mathrm{ppm})$ & 13.00 \\
& & Zn (ppm) & 1.00 \\
\hline
\end{tabular}

\subsubsection{Assessment of Chlorophyll and Proline Content}

The chlorophyll contents of the leaf samples were estimated following the procedure described by Arnon [38] and expressed as $\mathrm{mg} \mathrm{g}^{-1}$ of fresh weight. Weighed quantities of leaf samples $(0.5 \mathrm{~g})$ were collected from the third fully expanded leaves and cut into small pieces. These pieces were put into test tubes and incubated overnight at room temperature with $10 \mathrm{~mL}$ of DMSO and an $80 \%$ acetone mixture $(1: 1 \mathrm{v} / \mathrm{v})$. The colored solution was transferred into a measuring cylinder, and the absorbance was measured at $663 \mathrm{~nm}$ and $645 \mathrm{~nm}$.

Proline colorimetric determination proceeded according to the method by Bates et al. [39], based on proline's reaction with ninhydrin. Fresh leaf tissue $(0.5 \mathrm{~g})$ was homogenized in $10 \mathrm{~mL}$ of $3 \%$ sulfosalicylic acid in ice. The homogenate was centrifuged at $11,500 \times g$ for $15 \mathrm{~min}$. Then, $2 \mathrm{~mL}$ of the filtrate was mixed with $2 \mathrm{~mL}$ of acid ninhydrin and $2 \mathrm{~mL}$ of glacial acetic acid. After incubation at $100{ }^{\circ} \mathrm{C}$ for $1 \mathrm{~h}$, the mixture was cooled, and $4 \mathrm{~mL}$ of toluene was added. The optical density of the chromophore containing toluene was read spectrophotometrically at $520 \mathrm{~nm}$, using toluene as a blank. The amount of proline was estimated by comparison with a standard curve.

\subsubsection{Assessment of Enzymatic Antioxidants Activity}

Superoxide dismutase (SOD) activity (EC 1.15.1.1) was estimated based on the xanthine-xanthine oxidase system according to the method by Hossain et al. [40]. The reaction mixture contained $50 \mathrm{mM}$ of a KP buffer, $2.24 \mathrm{mM}$ of nitro blue tetrazolium (NBT), 0.1 units of catalase, $2.36 \mathrm{mM}$ of xanthine, and 0.1 unit of xanthine oxidase. Then, the change in the absorbance of the solution was recorded at $560 \mathrm{~nm}$ for $1 \mathrm{~min}$, and the activity of SOD was expressed as unit $\mathrm{mg}^{-1}$ protein (the amount of enzyme required to inhibit NBT reduction by $50 \%$ ). Peroxidase (POD) activity (EC: 1.11.1.7) was assessed following 
the method of Hemeda and Klein [41]. It was determined spectrophotometrically at $25{ }^{\circ} \mathrm{C}$ at $470 \mathrm{~nm}$ using guaiaco 1 and $\mathrm{H}_{2} \mathrm{O}_{2}$ as the hydrogen donor and substrate. The substrate

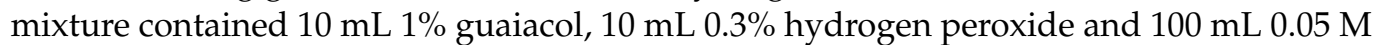
sodium phosphate buffer ( $\mathrm{pH}$ 6.5). Catalase (CAT) activity (EC: 1.11.1.6) was determined following the procedure of Csiszár et al. [42] by monitoring the decline in absorbance at $240 \mathrm{~nm}$ for $1 \mathrm{~min}$, and due to the degradation of $\mathrm{H}_{2} \mathrm{O}_{2}$, an extinction coefficient of $39.4 \mathrm{M}^{-1} \mathrm{~cm}^{-1}$ was used. The reaction mixture contained $50 \mathrm{mM} \mathrm{KP}$ buffer ( $\left.\mathrm{pH} 7.0\right)$, $15 \mathrm{mM} \mathrm{H}_{2} \mathrm{O}_{2}$, and an enzyme extract (the final volume was $700 \mu \mathrm{L}$ ).

\subsubsection{Morphological and Yield Contributing Attributes}

The morphological characters were measured after 92 days from sowing. Plant height (cm), the number of leaves per plant, the shoot fresh and dry weights $(\mathrm{g})$, and the root fresh and dry weights (g) were recorded. The yield-contributing characteristics assessed at harvest (92 DAS) included the number of branches per plant, the number of pods per plant, the number of seeds per pod, the thousand seed weight $(\mathrm{g})$, and seed yield (g/plant).

\subsection{Statistical Analysis}

The data for all the growth and physiological parameters were subjected to ANOVA, appropriate for a completely randomized design (CRD). Differences among treatments for all measurements were compared using LSD, and values were reported as significant at $p$-values of $<0.01$. All analyses were applied using $\mathrm{R}$ statistical software version 4.4.1.

\section{Results}

3.1. Laboratory Experiment

\subsubsection{Survival Percentage}

At the seedling stage, 119 diverse sesame genotypes were grown under four durations of waterlogged conditions $(12,24,48$, and $72 \mathrm{~h}$ ) to identify tolerant and sensitive genotypes. All genotypes died after $72 \mathrm{~h}$ of waterlogged conditions; however, 16, 38, and 54 genotypes survived after 48,24 , and $12 \mathrm{~h}$ of waterlogged conditions, respectively (Table 3 ). The mortality percentages varied from $54.2 \%$ to $100 \%$ under 12 to $72 \mathrm{~h}$ of waterlogging (Figure 1 ).

Table 3. List of sesame genotypes that survived under varying durations of waterlogged conditions at the seedling stage.

\begin{tabular}{|c|c|c|}
\hline Waterlogging Duration & Survived Sesame Genotypes & Number \\
\hline $12 \mathrm{~h}$ & $\begin{array}{l}\text { S. local, BARI-Til-3, BARI-Til-4, BD-6959, BD-6960, BD-6964, } \\
\text { BD-6966, BD-6970, BD-6972, BD-6974, BD-6978, BD-6979, BD-6980, } \\
\text { BD-6981, BD-6984, BD-6985, BD-6986, BD-6987, BD-6989, BD-6991, } \\
\text { BD-6993, BD-6994, BD-6996, BD-6998, BD-6997, BD-7000, BD7001, } \\
\text { BD-7003, BD-7004, BD 7005, BD-7007, BD-7008, BD 7011, BD-7012, } \\
\text { BD-7013, BD-7018, BD-7020, BD-7021, BD-7026, JP-00411, } \\
\text { JP-00515, JP-01611-2, JP-03013, JP-14003, JP-14004, JP-140016, } \\
\text { GP-5, GP-21, GP-35-2, GP-53-1, GP-83-1, GP-83-3, GP-160, GP-694 }\end{array}$ & 54 \\
\hline $24 \mathrm{~h}$ & $\begin{array}{l}\text { S. local, BARI-Til-3, BARI-Til-4, BD-6959, BD-6970, BD-6978, } \\
\text { BD-6980, BD-6981, BD-6984, BD-6989, BD-6991, BD-6996, BD-6997, } \\
\text { BD-6998, BD-6994, BD-7000, BD-7003, BD-7004, BD-7008, BD-7012, } \\
\text { BD-7018, BD-7021, BD-7026, JP-00411, JP- 01611-2, JP-01811, } \\
\text { JP-14003, JP-14004, JP-140016, BD-6985, JP-03013, GP-5, GP-21, GP } \\
\text { 35-2, GP-53-1, GP 83-1, GP 83-3, GP-160 }\end{array}$ & 38 \\
\hline $48 \mathrm{~h}$ & $\begin{array}{c}\text { BARI-Til-4, BD-6959, BD-6985, BD-6991, BD-6996, BD-6998, } \\
\text { BD-7008, BD-7004, BD-7018, JP-01811, JP-00411, JP-03013, } \\
\text { JP-14003, GP-5, GP-53-1, GP-83-3 }\end{array}$ & 16 \\
\hline $72 \mathrm{~h}$ & - & 0 \\
\hline
\end{tabular}




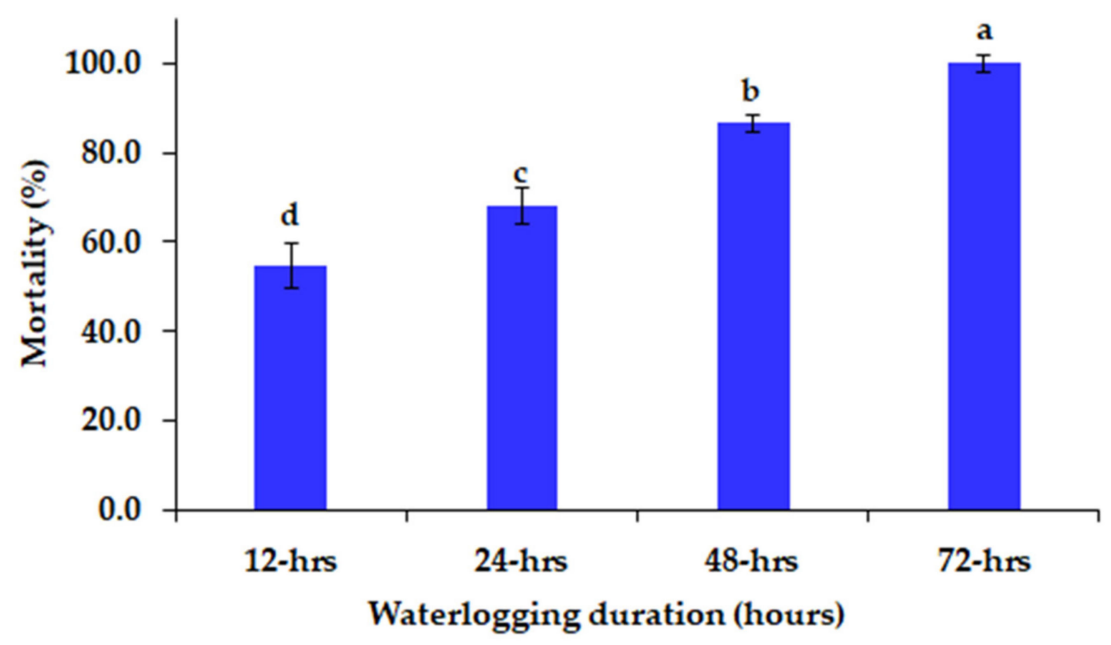

Figure 1. Mortality percentages of different sesame genotypes at the seedling stage under different durations of waterlogged conditions. The bars on the columns represent the SE, and different letters differ significantly by LSD $(p<0.01)$.

The survival percentages were calculated for sixteen genotypes that survived under 12,24 , and $48 \mathrm{~h}$ of waterlogged conditions, and they are presented in Table 4 . The survival percentages varied from $40 \%$ (JP-01811 and BD-6996) to 100\% (BD-6985) under $48 \mathrm{~h}$ of water stress. The maximum survival rate was recorded for genotypes BD-6985 and BD$7008(100 \%)$, and the lowest survival rate was recorded for JP-01811 (40\%) under $48 \mathrm{~h}$ of water stress.

Table 4. Pattern of survivability percentages of sixteen sesame genotypes in waterlogged conditions at 12,24 , and $48 \mathrm{~h}$.

\begin{tabular}{ccccc}
\hline & & \multicolumn{3}{c}{ Survivability (\%) } \\
\cline { 3 - 5 } No. & Genotypes & $\mathbf{1 2} \mathbf{h}$ & $\mathbf{2 4} \mathbf{h}$ & $\mathbf{4 8 ~ h}$ \\
\hline 1 & BD-6998 & 100 & 100 & 90 \\
2 & BD-6985 & 100 & 100 & 100 \\
3 & JP-00411 & 100 & 100 & 90 \\
4 & JP-03013 & 100 & 100 & 90 \\
5 & JP-14003 & 100 & 100 & 90 \\
6 & BD-7004 & 100 & 90 & 90 \\
7 & BD-7008 & 100 & 100 & 900 \\
8 & BD-7018 & 100 & 100 & 60 \\
9 & BD-6991 & 100 & 80 & 45 \\
10 & BD-6996 & 100 & 70 & 40 \\
11 & JP-01811 & 100 & 60 & 50 \\
12 & GP-83-3 & 100 & 70 & 50 \\
13 & GP-53-1 & 100 & 70 & 50 \\
14 & BD-6959 & 100 & 70 & 60 \\
15 & BARI Til 4 & 100 & 65 & 50 \\
16 & GP-5 & 100 & 65 & \\
\hline
\end{tabular}

\subsubsection{Seedling Measurements}

The genotypes BARI-Til-4, BD-6959, GP-83-3, JP-01811, BD-7018, and BD-7004 exhibited the tallest lengths under control conditions (Figure 2A). In addition, BD-7018, BD-7008, BD-6998, JP-14003, JP-03013, BD-7004, BD-6985, and JP-00411 displayed the highest seedling length values after $48 \mathrm{~h}$ of waterlogging. On the contrary, the lowest seedling length values were recorded for BD-6996, BD-6991, and GP-83-3. Genotypes BD-6996, BD-6985, GP-5, BD-7018, JP-14003, and JP-03013 presented the highest values of fresh seedling weight under control conditions (Figure 2B), while BD-6985, BD-7004, BD-6998, BD-7018, JP-14003, 
JP-03013, JP-00411, and BD-7008 presented the highest fresh weights under waterlogging at 48 h. BD-6996, JP-01811, and BD-6991 exhibited the lowest fresh weights.
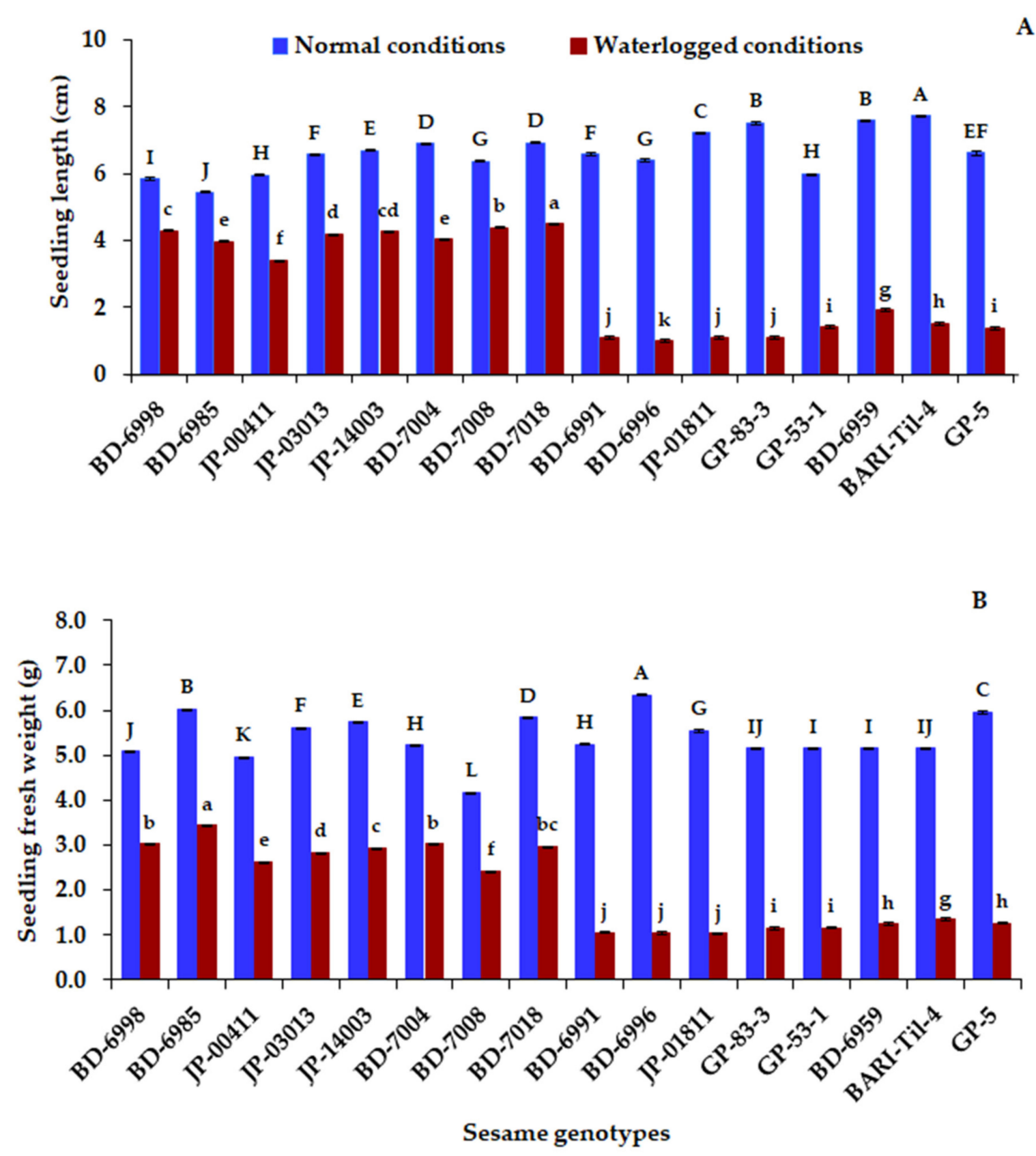

Figure 2. Seedling lengths (A) and fresh weights (B) of sixteen sesame genotypes under $48 \mathrm{~h}$ of waterlogging. Different uppercase letters indicate significant differences by LSD $(p<0.01)$ under normal conditions, while lowercase letters indicate waterlogged conditions.

\subsubsection{Waterlogging Tolerance and Growth Inhibition}

The waterlogging tolerance coefficients and growth inhibition rates were estimated for the sixteen sesame genotypes at the seedling stage under $48 \mathrm{~h}$ of waterlogging (Table 5). The genotypes responded differently to waterlogging stress. Genotypes BD-7008 and BD-6985 demonstrated the highest tolerance coefficient values and lowest inhibition percentages. On the contrary, BD-6996 and JP-01811 presented the lowest tolerance coefficient values and the highest inhibition percentages. Accordingly, these four genotypes were selected to be evaluated in the pot experiment. 
Table 5. Growth inhibition rates and waterlogging tolerance coefficients (WTCs) at the seedling stage of sixteen sesame genotypes under waterlogged conditions for $48 \mathrm{~h}$.

\begin{tabular}{|c|c|c|c|c|c|}
\hline No. & Genotype & $\begin{array}{l}\text { Inhibition \% of } \\
\text { Seedling Length }\end{array}$ & $\begin{array}{l}\text { Inhibition } \% \text { of } \\
\text { Seedling Weight }\end{array}$ & $\begin{array}{c}\text { WTC } \\
\text { (Length) }\end{array}$ & $\begin{array}{c}\text { WTC } \\
\text { (Fresh Weight) }\end{array}$ \\
\hline 1 & BD-6998 & $32.66^{j}$ & $42.28^{\mathrm{k}}$ & $0.67^{c}$ & $0.54^{\mathrm{b}}$ \\
\hline 2 & BD-6985 & $28.03^{1}$ & $40.21^{1}$ & $0.72^{\mathrm{a}}$ & $0.60^{\mathrm{a}}$ \\
\hline 3 & JP-00411 & $42.87^{g}$ & $47.39^{j}$ & $0.56^{\mathrm{k}}$ & $0.53^{b c}$ \\
\hline 4 & JP-03013 & $35.86^{\mathrm{i}}$ & $49.20^{\mathrm{i}}$ & $0.64^{\text {ef }}$ & $0.51^{\mathrm{c}}$ \\
\hline 5 & JP-14003 & $35.69^{\mathrm{i}}$ & $48.56^{\mathrm{ij}}$ & $0.66^{\mathrm{cd}}$ & $0.51^{\mathrm{c}}$ \\
\hline 6 & BD-7004 & $40.95^{\mathrm{h}}$ & $42.18^{k}$ & $0.59 \mathrm{~g}$ & $0.58^{\mathrm{a}}$ \\
\hline 7 & BD-7008 & $30.86^{k}$ & $40.49^{1}$ & $0.69^{b}$ & $0.59^{a}$ \\
\hline 8 & BD-7018 & $35.15^{\mathrm{i}}$ & $48.83^{\mathrm{i}}$ & $0.65^{\mathrm{de}}$ & $0.51^{\mathrm{c}}$ \\
\hline 9 & BD-6991 & $84.60^{b}$ & $64.81^{\mathrm{h}}$ & $0.15^{\circ}$ & $0.35^{\mathrm{d}}$ \\
\hline 10 & BD-6996 & $85.39^{b}$ & $83.61^{b}$ & $0.15^{\circ}$ & $0.16^{\mathrm{h}}$ \\
\hline 11 & JP-01811 & $87.56^{\mathrm{a}}$ & $86.82^{a}$ & $0.15^{\circ}$ & $0.18^{\mathrm{h}}$ \\
\hline 12 & GP-83-3 & $85.33^{b}$ & $81.71^{\mathrm{c}}$ & $0.12^{\mathrm{p}}$ & $0.23 \mathrm{fg}$ \\
\hline 13 & GP-53-1 & $77.07^{\mathrm{e}}$ & $77.65^{\mathrm{e}}$ & $0.23^{\mathrm{m}}$ & $0.22 \mathrm{fg}$ \\
\hline 14 & BD-6959 & $75.15^{f}$ & $75.94^{\mathrm{f}}$ & $0.25^{1}$ & 0.24 ef \\
\hline 15 & BARI-Til-4 & $80.27^{c}$ & $73.74 \mathrm{~g}$ & $0.20^{\mathrm{n}}$ & $0.26^{\mathrm{e}}$ \\
\hline 16 & GP-5 & $79.08^{d}$ & $78.98^{d}$ & $0.20^{n}$ & $0.21^{\mathrm{g}}$ \\
\hline
\end{tabular}

Means followed by the different letters are significantly different by the LSD at $p<0.01$.

\subsection{Pot Experiment}

3.2.1. Physiological Response to Waterlogged Conditions

Waterlogging immensely reduced the chlorophyll content in all evaluated genotypes (Figure 3A). Genotypes BD-7008 and BD-6985 exhibited the highest chlorophyll contents under normal and waterlogged conditions, while JP-01811 and BD-6996 displayed the lowest values (Figure 3A). Additionally, the proline content increased under waterlogging compared to normal conditions (Figure 3B). Genotype BD-7008, followed by BD-6985, exhibited the highest values of proline content under waterlogged conditions, while the lowest values were presented by JP-01811 and BD-6996.

Enzymatic antioxidant (SOD, POD, and CAT) activities increased in all genotypes under waterlogged conditions compared to normal conditions (Figure 4). Genotype BD7008 exhibited the highest activities of SOD, POD, and CAT under waterlogged conditions, followed by BD-6985, while the lowest values were exhibited by JP-01811 and BD-6996. Genotype BD-7008 displayed 41.7, 42.5, and 29.9\% increases in SOD, POD, and CAT, respectively, under waterlogged conditions compared to control conditions. Similarly, BD6985 exhibited increases in SOD, POD, and CAT by 28.4, 31.3, and 25.8\%, respectively, under waterlogged conditions compared to normal conditions. In contrast, JP-01811 presented the lowest increases in SOD, POD, and CA, with values of 17.2, 9.4, and 6.9\% under waterlogged conditions, compared to normal conditions.

\subsubsection{Morphological Characters}

The evaluated genotypes exhibited significant differences in plant height, the number of leaves per plant, the number of branches per plant, shoot fresh weight, shoot dry weight, root fresh weight, and root dry weight (Table 6). Genotypes BD-6985 and BD-7008 presented the highest values of all the aforementioned characteristics (Table 6). In contrast, JP-01811 and BD-6996 displayed the lowest values of all growth parameters. The main effect of BD-6985 surpassed BD-6996 in all the above-mentioned characteristics by 44.4, 28.6, $28.9,17.6,16.3,19.5$, and $31.7 \%$, respectively. Waterlogging stress, at all investigated growth stages, significantly decreased the growth parameters compared to normal conditions. However, waterlogging at 30 DAS steeply and significantly decreased all morphological characters compared to the other stages (Table 6). 
Conversely, the least hazardous stage was recorded for 40 DAS, compared to 30 and 50 DAS. Waterlogging at 30 DAS decreased the plant height, the number of leaves per plant, the number of branches per plant, shoot fresh weight, shoot dry weight, fresh root weight, and root dry weight by 13.0, 28.9, 40.9, 27.7, 21.0, 18.6, and $23.7 \%$, respectively, in comparison to normal conditions. In addition, waterlogging at $40 \mathrm{DAS}$ reduced the characteristics by $3.4,10.6,17.2,9.9,13.0,11.4$, and $7.9 \%$, respectively, compared to normal conditions. Moreover, waterlogging at 50 DAS reduced the aforementioned characteristics by $8.2,16.9,31.1,18.5,21.3,5.7$, and $10.5 \%$, respectively, compared to control conditions. The growth parameters significantly differed among the genotypes with each waterlogging treatment (Table 6). Waterlogging at all investigated growth stages substantially decreased the growth parameters compared to normal conditions. Similar to the results of the main effects, genotypes BD-6985 and BD-7008 exceeded BD-01811 and BD-6996 in all growth parameters under all waterlogging treatments. Additionally, the interaction results ascertained that the 30 DAS growth stage was the most sensitive growth stage for waterlogging stress for all the evaluated genotypes. The lowest values of all growth parameters occurred with waterlogging at $30 \mathrm{DAS}$ for all genotypes compared to the other treatments (Table 6). However, the 40 DAS growth stage was more tolerant than 30 and 50 DAS.
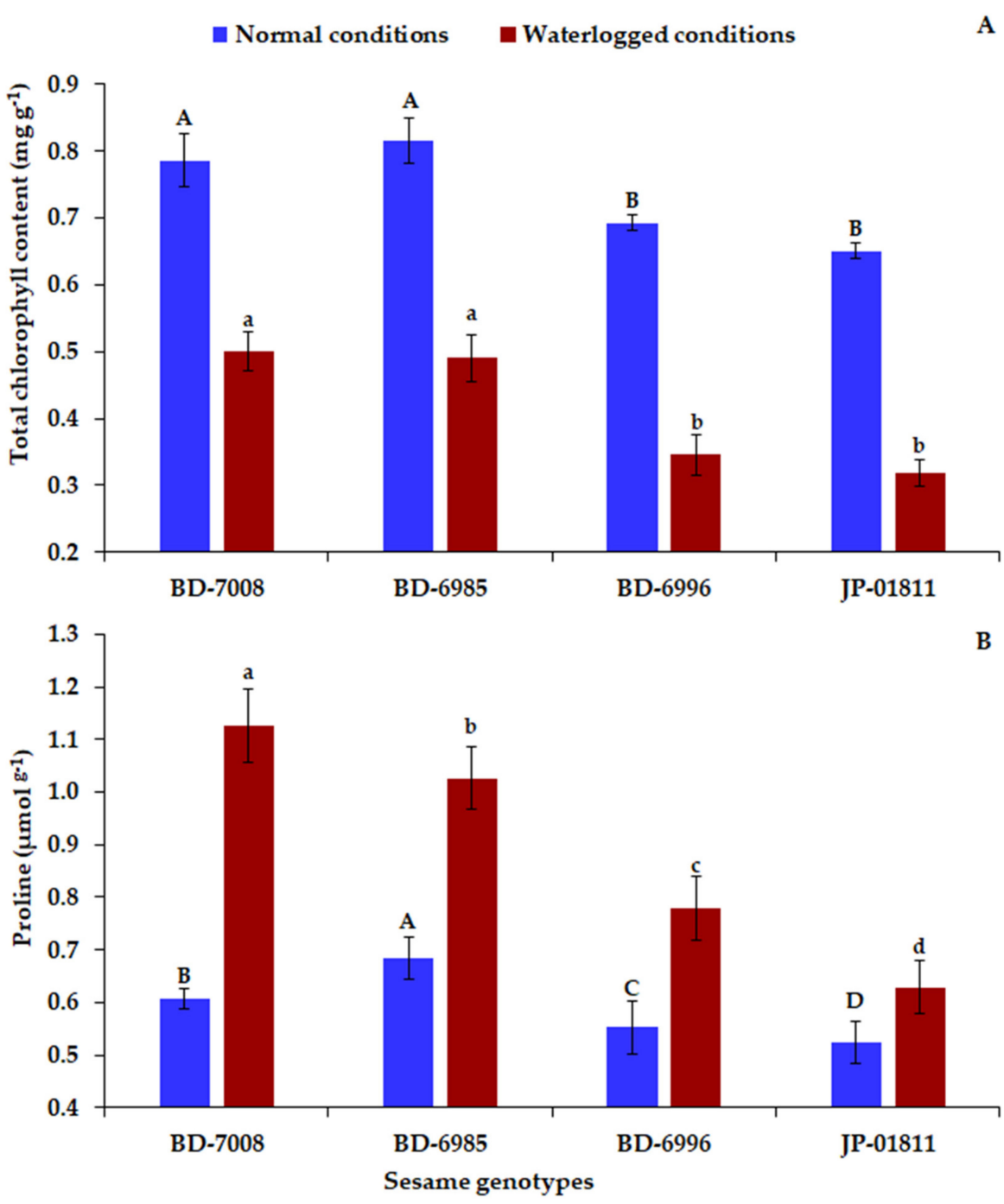

Figure 3. Total chlorophyll (A) and proline (B) contents of the four sesame genotypes at $48 \mathrm{~h}$ of waterlogging treatment. The bars on the columns correspond to SE and different uppercase letters indicate significant differences by LSD $(p<0.01)$ under normal conditions, while lowercase letters indicate waterlogged conditions. 

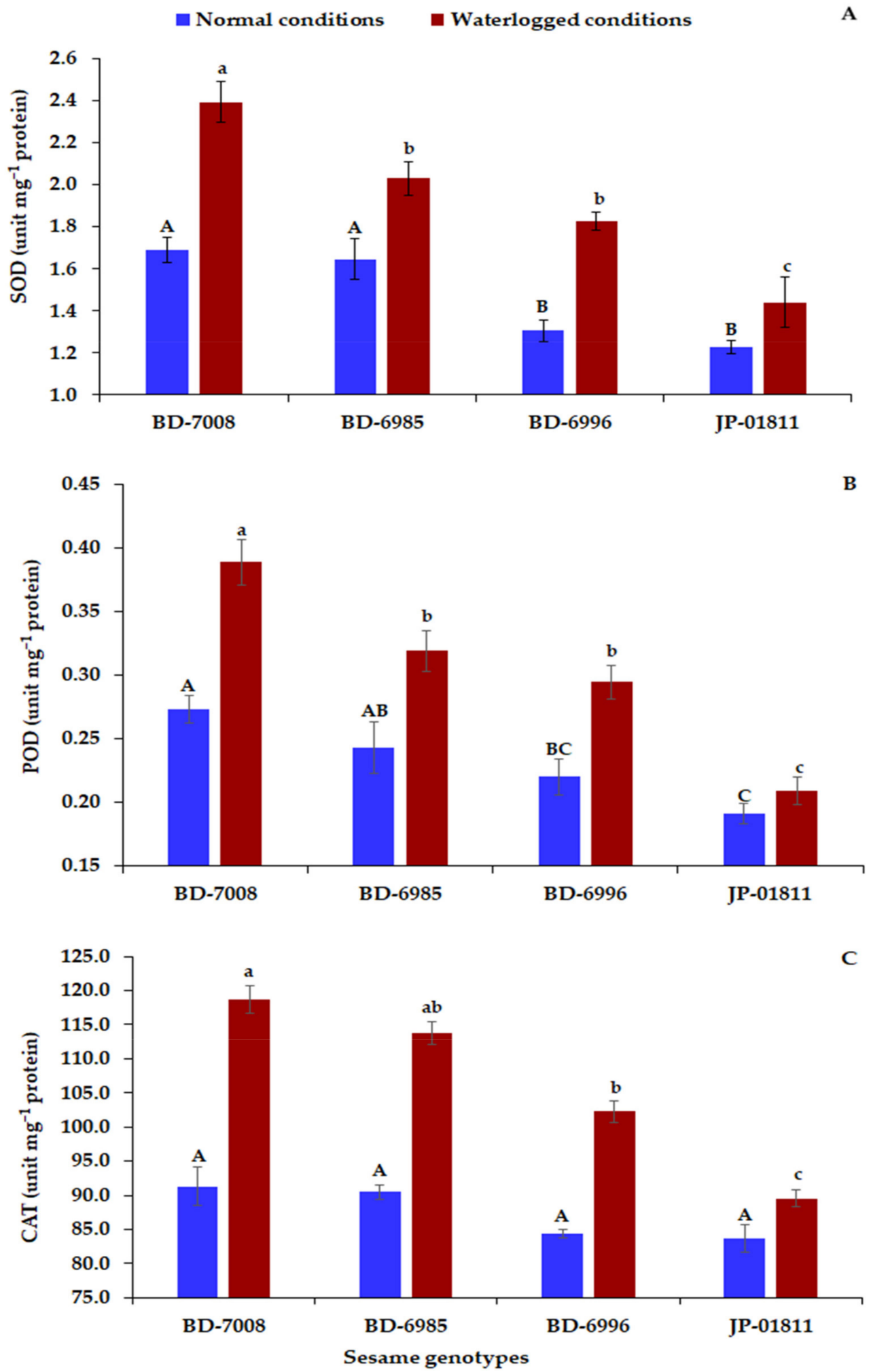

Figure 4. Impact of $48 \mathrm{~h}$ of waterlogged conditions on the activities of superoxide dismutase activity (SOD) (A), peroxidase (POD) (B), catalase (CAT) (C), and of four sesame genotypes. The bars on the columns correspond to SE and different uppercase letters indicate significant differences by LSD $(p<0.01)$ under normal conditions, while lowercase letters indicate waterlogged conditions. 
Table 6. Growth parameters of the sesame genotypes as influenced by waterlogging stress at different growth stages.

\begin{tabular}{|c|c|c|c|c|c|c|c|c|}
\hline \multicolumn{2}{|c|}{ Studied Factors } & $\mathbf{P H}$ & $\mathbf{N L} / \mathbf{P}$ & $\mathbf{N B} / \mathbf{P}$ & SFW & SDW & RFW & RDW \\
\hline \multicolumn{9}{|c|}{ Genotype (G) } \\
\hline \multicolumn{2}{|c|}{ BD-7008 } & $93.25^{b}$ & $20.91^{b}$ & $8.50^{\mathrm{a}}$ & $20.01^{\mathrm{a}}$ & $2.65^{b}$ & $3.55^{\mathrm{a}}$ & $0.74^{b}$ \\
\hline \multicolumn{2}{|c|}{ BD-6985 } & $98.66^{\mathrm{a}}$ & $23.67^{a}$ & $8.91^{\mathrm{a}}$ & $20.54^{\mathrm{a}}$ & $2.85^{a}$ & $3.00^{b}$ & $0.79^{\mathrm{a}}$ \\
\hline \multicolumn{2}{|c|}{ BD-6996 } & $68.33^{c}$ & $18.41^{\mathrm{C}}$ & $6.91^{\mathrm{b}}$ & $17.47^{\mathrm{b}}$ & $2.45^{\mathrm{c}}$ & $2.51^{\mathrm{c}}$ & $0.60^{c}$ \\
\hline \multicolumn{2}{|c|}{ JP-01811 } & $70.75^{c}$ & $18.33^{\mathrm{c}}$ & $7.25^{b}$ & $16.98^{\mathrm{b}}$ & $2.39^{c}$ & $2.49^{\mathrm{c}}$ & $0.58^{c}$ \\
\hline \multicolumn{2}{|c|}{$p$-value $(\mathrm{G})$} & $<0.001$ & 0.018 & 0.021 & 0.05 & 0.016 & 0.005 & 0.011 \\
\hline \multicolumn{9}{|c|}{ Waterlogging growth stage(W) } \\
\hline \multicolumn{2}{|c|}{ Control } & $88.17^{a}$ & $23.67^{\mathrm{a}}$ & $10.16^{\mathrm{a}}$ & $21.80^{\mathrm{a}}$ & $3.00^{\mathrm{a}}$ & $3.17^{\mathrm{a}}$ & $0.76^{\mathrm{a}}$ \\
\hline \multicolumn{2}{|c|}{30 DAS } & $76.75^{\mathrm{d}}$ & $16.83^{\mathrm{d}}$ & $6.00^{c}$ & $15.77^{\mathrm{d}}$ & $2.37^{\mathrm{c}}$ & $2.58^{c}$ & $0.58^{c}$ \\
\hline \multicolumn{2}{|c|}{40 DAS } & $85.17^{b}$ & $21.16^{b}$ & $8.41^{b}$ & $19.64^{b}$ & $2.61^{b}$ & $2.81^{b}$ & $0.70^{\mathrm{ab}}$ \\
\hline \multicolumn{2}{|c|}{50 DAS } & $80.92^{c}$ & $19.67^{c}$ & $7.00^{c}$ & $17.77^{c}$ & $2.36^{c}$ & $2.99 \mathrm{ab}$ & $0.68^{b}$ \\
\hline \multicolumn{2}{|c|}{$p$-value $(\mathrm{W})$} & $<0.001$ & $<0.001$ & $<0.001$ & $<0.001$ & 0.011 & $<0.001$ & 0.002 \\
\hline \multicolumn{9}{|c|}{ Interaction $(G \times W)$} \\
\hline \multirow{3}{*}{ BD-7008 } & Control & $97.00^{\mathrm{a}}$ & $24.33^{\mathrm{a}}$ & $11.00^{\mathrm{a}}$ & $23.40^{\mathrm{a}}$ & $3.18^{a}$ & $3.80^{a}$ & $0.81^{a}$ \\
\hline & 30 DAS & $90.00^{b}$ & $17.66^{\mathrm{c}}$ & $6.33^{c}$ & $16.76^{\mathrm{d}}$ & $2.32^{c}$ & $3.18^{c}$ & $0.56^{c}$ \\
\hline & 40 DAS & $95.33^{\mathrm{a}}$ & $21.66^{b}$ & $9.33^{b}$ & $21.40^{b}$ & $2.77^{b}$ & $3.46^{b c}$ & $0.88^{a}$ \\
\hline \multirow{4}{*}{ BD-6985 } & 50 DAS & $90.67^{b}$ & $20.00^{b}$ & $7.33^{c}$ & $18.50^{\mathrm{c}}$ & $2.33^{c}$ & $3.75^{\mathrm{ab}}$ & $0.71^{b}$ \\
\hline & Control & $104.67^{\mathrm{a}}$ & $28.00^{a}$ & $11.66^{\mathrm{a}}$ & $24.30^{\mathrm{a}}$ & $3.49^{\mathrm{a}}$ & $3.49^{\mathrm{a}}$ & $0.93^{a}$ \\
\hline & 30 DAS & $91.33^{c}$ & $19.00^{\mathrm{d}}$ & $6.66^{c}$ & $17.10^{\mathrm{c}}$ & $2.54^{c}$ & $2.53^{c}$ & $0.69^{\mathrm{d}}$ \\
\hline & 40 DAS & $102.00^{\mathrm{a}}$ & $25.33^{b}$ & $9.66^{b}$ & $21.93^{b}$ & $2.81^{b}$ & $2.90^{b}$ & $0.80^{b}$ \\
\hline \multirow{5}{*}{ BD-6996 } & 50 DAS & $96.67^{b}$ & $22.33^{c}$ & $7.66^{c}$ & $18.83^{c}$ & $2.55^{c}$ & $3.06^{b}$ & $0.74^{\mathrm{c}}$ \\
\hline & Control & $72.33^{a}$ & $21.33^{a}$ & $8.66^{a}$ & $20.50^{\mathrm{a}}$ & $2.69^{a}$ & $2.75^{a}$ & $0.65^{a}$ \\
\hline & 30 DAS & $64.67^{\mathrm{c}}$ & $15.66^{c}$ & $5.33^{\mathrm{d}}$ & $14.80^{\mathrm{d}}$ & $2.32^{c}$ & $2.33^{c}$ & $0.51^{b}$ \\
\hline & 40 DAS & $69.00^{b}$ & $18.66^{b}$ & $7.33^{b c}$ & $17.76^{b}$ & $2.44^{b}$ & $2.44^{b c}$ & $0.61^{\mathrm{ab}}$ \\
\hline & 50 DAS & $67.33^{b}$ & $18.00^{b}$ & $6.33^{\mathrm{cd}}$ & $16.83^{c}$ & $2.35^{c}$ & $2.54^{b}$ & $0.64^{\mathrm{a}}$ \\
\hline \multirow{4}{*}{ JP-01811 } & Control & $78.67^{\mathrm{a}}$ & $21.00^{\mathrm{a}}$ & $9.33^{\mathrm{a}}$ & $19.03^{\mathrm{a}}$ & $2.64^{\mathrm{a}}$ & $2.64^{\mathrm{a}}$ & $0.64^{a}$ \\
\hline & 30 DAS & $61.00^{\mathrm{d}}$ & $15.00^{\mathrm{c}}$ & $5.66^{\mathrm{d}}$ & $14.40^{\mathrm{d}}$ & $2.31^{b c}$ & $2.27^{c}$ & $0.56^{b}$ \\
\hline & 40 DAS & $74.33^{b}$ & $19.00^{a b}$ & $7.33^{b c}$ & $17.46^{b}$ & $2.42^{b}$ & $2.44^{b c}$ & $0.51^{b}$ \\
\hline & 50 DAS & $69.00^{c}$ & $18.33^{b}$ & $6.66^{\mathrm{cd}}$ & $16.93^{c}$ & $2.20^{c}$ & $2.61^{\mathrm{ab}}$ & $0.61^{\mathrm{ab}}$ \\
\hline \multicolumn{2}{|c|}{$p$-value $(\mathrm{G} \times \mathrm{W})$} & $<0.001$ & 0.001 & 0.02 & 0.03 & 0.05 & 0.004 & 0.001 \\
\hline
\end{tabular}

$\mathrm{PH}$ is plant height (cm); NL/P is the number of leaves per plant; NB/P is the number of branches per plant; SFW is shoot fresh weight ( $\mathrm{g}$ ); SDW is shoot dry weight (g); RFW is root fresh weight (g); and RDW is root dry weight (g). Means followed by different letters under the same trait indicate significant differences by LSD $(p<0.01)$.

\subsubsection{Yield Traits}

The genotypes exhibited substantial differences in the number of pods per plant, number of seeds per pod, 1000-seed weight, days to fruit set, days to maturity, and seed yield per plant (Table 7). Genotypes BD-6985 and BD-7008 possessed the highest values of all the above-mentioned measured yield traits (Table 7). In contrast, JP-01811 and BD6996 showed the lowest values of all yield traits. The waterlogging treatments drastically decreased the yield traits compared to control conditions. Notably, waterlogging at 30 DAS severely and significantly reduced all yield traits compared to the other growth stages (Table 7). Waterlogging at $30 \mathrm{DAS}$ reduced the number of pods per plant, number of seeds per pod, 1000-seed weight, days to fruit set, days to maturity, and seed yield per plant by $8.1,8.1,30.3,6.8,5.5$, and $32.7 \%$, respectively, compared to normal conditions. The negative impact of waterlogging at 40 DAS was the lowest compared to 30 and 50 DAS; it reduced yield traits by $2.7,3.9,17.2,3.1,2.4$, and 18.8 , respectively, compared to the normal conditions. The interaction results prove that the yield traits of genotypes BD-6985 and BD-7008 under all waterlogging treatments were superior to BD-01811 and BD-6996. In addition, 30 DAS was the most sensitive growth stage for waterlogging stress, followed by 50 and 40 DAS in all the evaluated genotypes. 
Table 7. Yield-contributing traits of sesame genotypes as influenced by waterlogging stress at different growth stages.

\begin{tabular}{|c|c|c|c|c|c|c|c|}
\hline \multicolumn{2}{|c|}{ Studied Factors } & $\mathbf{N P} / \mathbf{P}$ & NS/P & TGW & DFS & DM & SY \\
\hline \multicolumn{8}{|c|}{ Genotype (G) } \\
\hline \multicolumn{2}{|c|}{ BD-7008 } & $35.75^{\mathrm{a}}$ & $66.83^{c}$ & $8.66^{a}$ & $57.41^{\mathrm{b}}$ & $76.66^{\mathrm{c}}$ & $0.87^{b}$ \\
\hline \multicolumn{2}{|c|}{ BD-6985 } & $35.66^{\mathrm{a}}$ & $68.83^{a}$ & $9.08^{a}$ & $58.33^{a}$ & $78.41^{\mathrm{a}}$ & $0.96^{\mathrm{a}}$ \\
\hline \multicolumn{2}{|c|}{ BD-6996 } & $35.75^{\mathrm{a}}$ & $68.17^{a b}$ & $7.41^{b}$ & $57.08^{b c}$ & $77.58^{b}$ & $0.72^{\mathrm{c}}$ \\
\hline \multicolumn{2}{|c|}{ JP-01811 } & $35.50^{\mathrm{a}}$ & $67.75^{b c}$ & $7.66^{b}$ & $56.91^{c}$ & $76.91^{\mathrm{bc}}$ & $0.70^{\mathrm{c}}$ \\
\hline \multicolumn{2}{|c|}{$p$-value } & 0.048 & 0.021 & 0.031 & 0.008 & 0.004 & 0.001 \\
\hline \multicolumn{8}{|c|}{ Waterlogging growth stage (W) } \\
\hline \multicolumn{2}{|c|}{ Control } & $37.08^{a}$ & $71.08^{\mathrm{a}}$ & $10.16^{a}$ & $59.75^{a}$ & $79.75^{a}$ & $1.01^{\mathrm{a}}$ \\
\hline \multicolumn{2}{|c|}{30 DAS } & $34.08^{c}$ & $65.33^{d}$ & $7.08^{c}$ & $55.66^{\mathrm{d}}$ & $75.33^{c}$ & $0.68^{c}$ \\
\hline \multicolumn{2}{|c|}{40 DAS } & $36.08^{a b}$ & $68.33^{b}$ & $8.41^{b}$ & $57.91^{b}$ & $77.83^{b}$ & $0.82^{b}$ \\
\hline \multicolumn{2}{|c|}{50 DAS } & $35.16^{b c}$ & $66.83^{c}$ & $7.20^{c}$ & $56.41^{\mathrm{c}}$ & $76.66^{b c}$ & $0.73^{b}$ \\
\hline \multicolumn{2}{|c|}{$p$-value } & 0.035 & 0.005 & 0.022 & 0.019 & 0.014 & 0.001 \\
\hline \multicolumn{8}{|c|}{ Interaction $(G \times W)$} \\
\hline \multirow{4}{*}{ BD-7008 } & Control & $37.33^{\mathrm{a}}$ & $70.66^{\mathrm{a}}$ & $11.00^{\mathrm{a}}$ & $60.66^{a}$ & $80.66^{a}$ & $1.13^{\mathrm{a}}$ \\
\hline & 30 DAS & $34.66^{\mathrm{b}}$ & $65.00^{b}$ & $7.00^{\mathrm{c}}$ & $55.66^{c}$ & $74.33^{c}$ & $0.69^{\mathrm{c}}$ \\
\hline & 40 DAS & $35.33^{b}$ & $66.00^{b}$ & $9.30^{b}$ & $58.00^{b}$ & $76.66^{b}$ & $0.86^{b}$ \\
\hline & $50 \mathrm{DAS}$ & $34.66^{b}$ & $65.66^{b}$ & $7.33^{c}$ & $55.33^{c}$ & $75.00^{\mathrm{c}}$ & $0.81^{b}$ \\
\hline \multirow{4}{*}{ BD-6985 } & Control & $37.00^{\mathrm{a}}$ & $72.66^{\mathrm{a}}$ & $11.66^{\mathrm{a}}$ & $61.33^{\mathrm{a}}$ & $81.00^{a}$ & $1.11^{\mathrm{a}}$ \\
\hline & 30 DAS & $33.66^{c}$ & $66.00^{c}$ & $7.33^{c}$ & $56.00^{\mathrm{d}}$ & $76.66^{c}$ & $0.85^{c}$ \\
\hline & 40 DAS & $36.66^{\mathrm{a}}$ & $69.66^{b}$ & $9.66^{b}$ & $58.66^{b}$ & $78.33^{b}$ & $1.00^{b}$ \\
\hline & $50 \mathrm{DAS}$ & $35.33^{b}$ & $67.00^{b c}$ & $7.66^{c}$ & $57.33^{c}$ & $77.66^{b}$ & $0.86^{c}$ \\
\hline \multirow{4}{*}{ BD-6996 } & Control & $36.66^{a}$ & $70.66^{a}$ & $8.66^{a}$ & $58.66^{a}$ & $79.00^{\mathrm{a}}$ & $0.86^{a}$ \\
\hline & 30 DAS & $34.66^{b}$ & $65.00^{c}$ & $6.66^{b}$ & $55.33^{c}$ & $75.33^{c}$ & $0.64^{\mathrm{d}}$ \\
\hline & $40 \mathrm{DAS}$ & $36.00^{\mathrm{a}}$ & $69.00^{b}$ & $7.33^{b}$ & $57.66^{a b}$ & $78.66^{a}$ & $0.72 \mathrm{bc}$ \\
\hline & 50 DAS & $35.66^{a b}$ & $68.00^{b}$ & $7.0^{b}$ & $56.66^{b}$ & $77.33^{b}$ & $0.67^{c}$ \\
\hline \multirow{4}{*}{ JP-01811 } & Control & $37.33^{\mathrm{a}}$ & $70.33^{a}$ & $9.33^{a}$ & $58.33^{\mathrm{a}}$ & $78.33^{a}$ & $0.94^{\mathrm{a}}$ \\
\hline & $30 \mathrm{DAS}$ & $33.33^{c}$ & $65.33^{c}$ & $7.33^{b}$ & $55.66^{c}$ & $75.00^{\mathrm{c}}$ & $0.57^{\mathrm{c}}$ \\
\hline & 40 DAS & $36.33^{\mathrm{a}}$ & $68.66^{b}$ & $7.33^{b}$ & $57.33^{\mathrm{ab}}$ & $77.66^{\mathrm{ab}}$ & $0.71^{b}$ \\
\hline & $50 \mathrm{DAS}$ & $35.00^{b}$ & $66.66^{c}$ & $6.66^{b}$ & $56.33^{b c}$ & $76.66^{b}$ & $0.58^{c}$ \\
\hline$p$-value & & 0.018 & 0.041 & 0.021 & 0.037 & 0.011 & 0.048 \\
\hline
\end{tabular}

$\mathrm{NP} / \mathrm{P}$ is the number of pods per plant; NS/P is the number of seeds per pod; TGW is the 1000-seed weight (g); DFS is days to fruit set (days); DM is days to maturity (days); and SY is seed yield (g/plant). Means followed by different letters under the same trait indicate significant differences by LSD $(p<0.01)$.

\subsubsection{Interrelationships among the Evaluated Traits and Treatments}

Principal component analysis (PCA) was applied in order to study the relationships among the evaluated traits and treatments, as displayed in Figure 5. The first two PCAs explained $91.59 \%$ of the variability. PCA1 accounted for $78.10 \%$ of the variation and appears to be associated with the waterlogging treatments. Regardless of the genotypes, the normal conditions (Cont) are situated on the positive side of PCA1, followed by waterlogging at 40 and 50 DAS and, finally, waterlogging at 30 DAS on the end of the negative side of PCA1. PCA2 accounted for $13.49 \%$ of the variation and appears to be related to sesame genotypes in the following order: BD-7008, BD-6985, JP-01811, and BD-6996. PCA2 divided the genotypes into two groups: the tolerant ones, BD-7008 and BD-6985, are situated on the positive side of the axis, and the sensitive ones, BD-6996 and JP-01811, are located on the negative side of the axis. Notably, the sensitive genotypes, BD-6996 and JP-01811, experienced minor effects, as described by the slight distances in the multi-dimensional space compared to the tolerant ones, BD-7008 and BD-6985, which are more scattered, inferring dissimilarity (Figure 5). As presented previously, the seed yield and its attributes are positively associated with the normal conditions (along the positive side of the PCA1 axis) and negatively associated with waterlogging at 30 DAS, which is further along the PCA2 axis. The adjacent vectors of seed yield and all its attributes reflect a positive association. Indeed, seed yield was strongly associated with the 1000-seed weight, the number of branches per plant, shoot fresh weight, shoot dry weight, and the number of leaves per plant. 


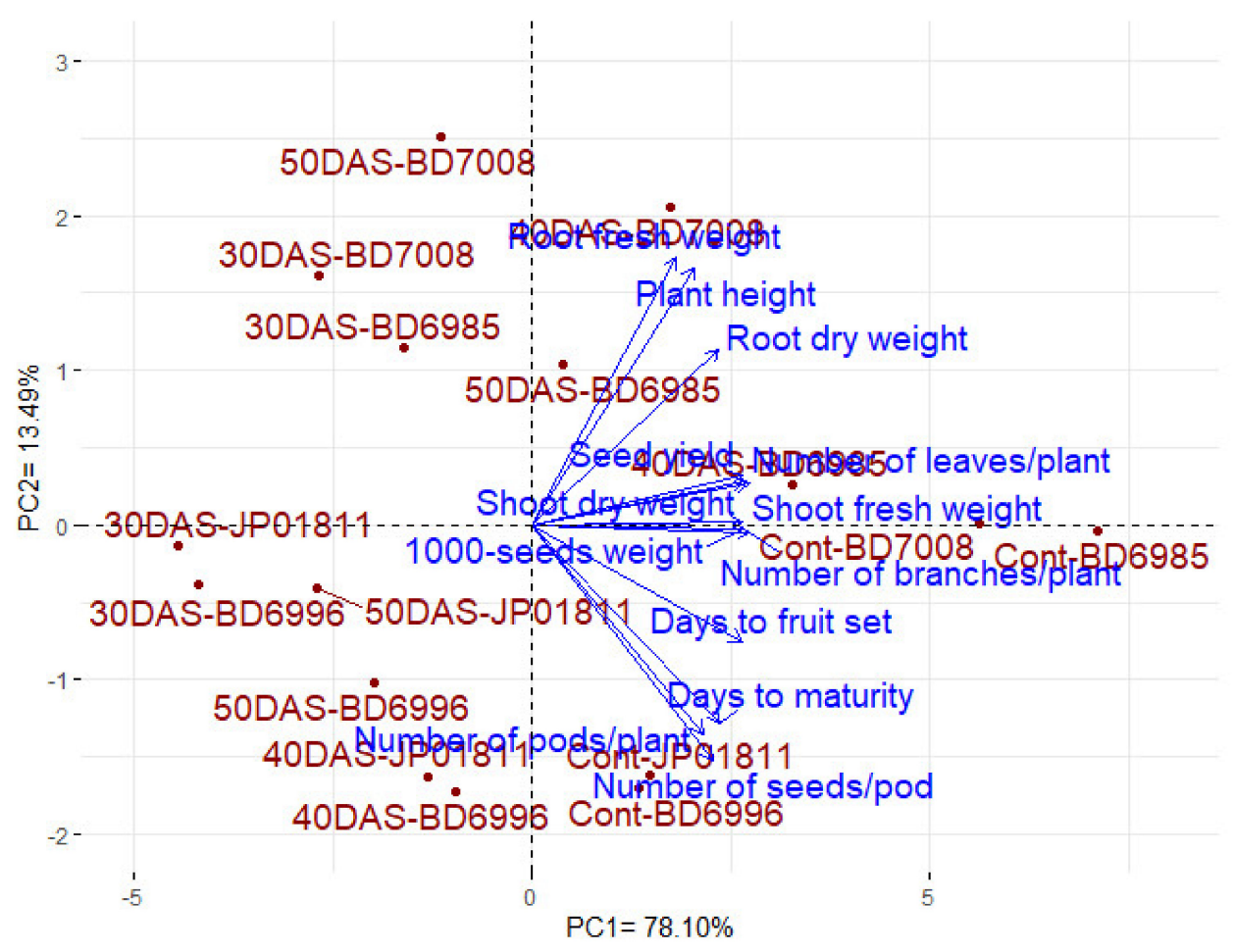

Figure 5. PCA biplot for the evaluated traits of four sesame genotypes (BD-7008, BD-6985, BD-6996, and JP-01811) under four waterlogging treatments-control, 30, 40, and 50 days after sowing, which are presented as Cont, 30D, 40D, and 50D.

\section{Discussion}

Waterlogging is one of the major abiotic stresses that cause biochemical, physiological, anatomical, and morphological alterations that translate into severe crop yield losses [43]. It initiates hypoxia (low oxygen) or anoxia (absence of oxygen), which leads to direct root damage and indirect leaf wilting under transient or sustained flooded conditions [44]. Climate change is expected to bring no rainfall for long periods, followed by heavy and prolonged precipitation, causing devastating floods [45,46]. Subsequently, field crops will face flooded conditions, leading to a drastic global reduction in food production. Accordingly, developing flood-tolerant genotypes has become urgent in order to cope with these constraints. Sesame is very sensitive to waterlogging; nevertheless, there are considerable differences among its genotypes [6,7]. Therefore, it is necessary to screen diverse sesame genetic resources under different waterlogging durations to assess their levels of flooding tolerance. In the present study, 119 diverse sesame genotypes were evaluated at the seedling stage under four waterlogging durations versus normal, nonwaterlogged conditions. Seedling tests under controlled conditions are commonly carried out to screen for waterlogging tolerance [47]. Genetic variability for flooding tolerance can be assessed indirectly by survival percentage and crop damage indices [48]. The survival percentage was estimated, and it substantially varied between waterlogging durations. After $72 \mathrm{~h}$ of waterlogging, all the genotypes died, while the maximum survival (45.38\%) was recorded at $12 \mathrm{~h}$. Prolonged periods of waterlogging cause the complete absence of oxygen (anoxia), which inhibits the ability of roots to supply water and nutrients, hinders respiration and photosynthesis, and causes root rot and death [49-52]. Accordingly, all genotypes died after $72 \mathrm{~h}$ of waterlogging, while 16 survived after $48 \mathrm{~h}, 38$ after $24 \mathrm{~h}$, and 54 after $12 \mathrm{~h}$ of waterlogged conditions.

Waterlogging tolerance coefficients (WTCs) and seedling parameters were employed to distinguish the tolerant and sensitive genotypes out of the sixteen genotypes that survived under 12,24 , and $48 \mathrm{~h}$ of waterlogging. WTCs and seedling parameters can 
provide a reliable preliminary picture of the tolerance and sensitivity of sesame genotypes to flooding. Higher values expressed a higher tolerance to waterlogged conditions compared to lower ones. There was considerable variation among the sixteen sesame genotypes. Based on the WTCs and seedling parameters, genotypes BD-7008 and BD-6985 exhibited the highest tolerance to waterlogging, while BD-6996 and JP-01811 were the most sensitive ones. A pot experiment was applied to further investigate the response of tolerant and susceptible genotypes to waterlogging at different growth stages of 30,40, and 50 DAS versus normal, non-waterlogged conditions. The degree of adverse impacts of waterlogged soils depends on the plant growth stage, the duration of flooding, soil type, growth conditions, and genotypes $[44,53]$. The maximum growth and yield traits were obtained under the control condition (non-waterlogged), while the physiological, developmental, and agronomic traits were destructively affected by flooding for $48 \mathrm{~h}$, particularly at the early growth stage (30 DAS). Immediately after waterlogging, plants cannot follow any adaptive mechanisms, which results in the extreme unfitness of plants at the early stage of growth [54-56]. This is probably the reason that 30 DAS sesame exposed to waterlogging showed pronounced effects in all genotypes.

Under waterlogged conditions, the scavenging abilities of reactive oxygen species (ROS) of sesame normally decreased. The activities of enzymatic antioxidants have a crucial role in plant survival during prolonged flooding stress and preventing cell damage [57,58]. Therefore, the effective antioxidant system is positively and significantly associated with waterlogging tolerance. In the present study, the activities of the SOD, POD, CAT, and proline content increased in the tolerant sesame genotypes (BD-7008 and BD-6985) under waterlogged conditions compared to the sensitive ones (BD-6996 and JP 01811). Thus, the enzymic antioxidants provided a better balance between the ROS generated by waterlogging and detoxification, which enhanced the plant's ability to cope with flooding stress [59]. These results are in accordance with the previous findings of Sairam et al. [30], Damanik et al. [60], and Xu et al. [61], since they demonstrated higher activities of enzymatic antioxidants in the waterlogging-tolerant genotypes than the sensitive ones. Moreover, $\mathrm{Xu}$ et al. [61] depicted an increased proline content under flooding stress in the tolerant sesame genotypes compared to the sensitive ones. Proline acts as a vital osmolyte for osmotic adjustment and contributes to stabilizing cell structures and protecting membranes and proteins against ROS [62]. Therefore, the enzymatic antioxidants activities and proline content could be employed as indirect indices to screen sesame genotypes for waterlogging tolerance. Furthermore, the stimulating effects of antioxidants enzyme activities and proline attributed positively to ameliorating waterlogging tolerance and, hence, exhibited higher growth and productivity. Accordingly, the tolerant sesame genotypes exhibited significantly higher growth and yield traits than the sensitive ones. The results of the pot experiment confirm the results of the seedling trial regarding the classification of the sesame genotypes based on their tolerance to waterlogging. Therefore, the seedling parameters and waterlogging tolerance coefficients (WTCs) at the seedling stage are efficient and reliable measurements for distinguishing tolerant and sensitive genotypes to waterlogging stress.

The PC biplot is an efficient statistical analysis to visualize the interrelationships among the evaluated treatments and traits [63-66]. The present results indicate that waterlogging at 30 DAS was located on the extreme negative side of the PCA1 axis compared to the normal, non-waterlogged conditions on the positive side, while 40 and 50 DAS were intermediate. This corroborates that the most critical period for waterlogging stress is the early growth stage, at 30 DAS, compared to the other growth stages at 40 and 50 DAS. Moreover, the PC biplot displays the evaluated sesame genotypes in different patterns: the tolerant ones were situated on the positive side of the PCA2 axis, while the sensitive ones were located on the negative side. Furthermore, the PC biplot demonstrates the reduction in growth and seed yield traits due to waterlogging stress, as they are opposite to waterlogging at 30 DAS and are positively associated with the normal conditions. Seed yield had a strong association with the 1000-seed weight and the number of branches 
per plant, which could be employed as rapid and indirect indicators to seed yield under waterlogging stress.

\section{Conclusions}

The evaluated sesame genotypes possess distinct genetic diversity, which is reflected in their ability to survive under waterlogged conditions. Genotypes BD-7008 and BD-6985 are considered to be highly tolerant of waterlogging stress, while BD-6996 and JP-01811 are the most sensitive. The tolerant genotypes exhibited the highest activities of enzymatic antioxidants-SOD, POD, and CAT - and proline content, compared to the sensitive ones. Accordingly, these antioxidant enzymes and proline content could be indirect indices to screen sesame genotypes for waterlogging tolerance. The physiological, developmental, and agronomic traits were destructively affected by flooding, particularly at the early growth stage, at 30 DAS, compared to 40 and 50 DAS. Accordingly, the growth stage is critical to waterlogging stress. The results of the seedling experiment are consistent with the pot trial, based on identifying the waterlogging-tolerant and sensitive genotypes. Consequently, the seedling parameters and waterlogging tolerance coefficients are efficient and reliable measurements for distinguishing the genotypes that are tolerant or sensitive to waterlogging stress.

Author Contributions: Conceptualization, M.H., S.S., M.Z.R., M.M.I., K.U.A. and M.S.H.; methodology, M.H., S.S., M.Z.R., M.M.I., K.U.A. and M.S.H.; software, M.H., M.F.A., A.I.E., E.M. and M.S.H.; validation, M.H., S.S., M.Z.R., M.M.I., K.U.A. and M.S.H.; formal analysis, M.H., S.S., M.Z.R., M.M.I, K.U.A. and M.S.H.; investigation, M.H., S.S., M.Z.R., M.M.I., K.U.A. and M.S.H.; data curation, M.H., S.S., M.Z.R., M.M.I., K.U.A., M.F.A., A.I.E., E.M. and M.S.H.; writing—original draft preparation, M.H., M.F.A., A.I.E., E.M. and M.S.H.; writing-review and editing, M.H., S.S., M.Z.R., M.M.I, K.U.A., M.F.A., A.I.E., E.M. and M.S.H. All authors have read and agreed to the published version of the manuscript.

Funding: This research received no external funding.

Institutional Review Board Statement: Not applicable.

Informed Consent Statement: Not applicable.

Data Availability Statement: The data presented in this study are available from the corresponding author upon request.

Acknowledgments: The authors thank Ahmad A. Omar for his valuable revisions of the manuscript. The authors extend their appreciation to Taif University for funding this work through the Taif University Researchers Supporting Project, number (TURSP-2020/111), Taif University, Taif, Saudi Arabia.

Conflicts of Interest: The authors declare no conflict of interest.

\section{References}

1. Myint, D.; Gilani, S.A.; Kawase, M.; Watanabe, K.N. Sustainable sesame (Sesamum indicum L.) production through improved technology: An overview of production, challenges, and opportunities in Myanmar. Sustainability 2020, 12, 3515. [CrossRef]

2. FAOSTAT. Food and Agriculture Organization of the United Nations. Statistical Database. 2021. Available online: http: //www.fao.org/faostat/en/\#data (accessed on 26 July 2021).

3. Nagendra Prasad, M.; Sanjay, K.; Prasad, D.; Vijay, N.; Kothari, R.; Nanjunda Swamy, S. A review on nutritional and nutraceutical properties of sesame. J. Nutr. Food Sci. 2012, 2,1-6.

4. Ofosuhene-Sintim, H.; Yeboah-Badu, V. Evaluation of sesame (Sesamum indicum) production in Ghana. J. Anim. Plant Sci. 2010, 6, 653-662.

5. Ravitej, K.; Kumar, P.R.; Reddy, S.N.; Yadav, P.; Shankar, G.; Srikanth, B.; Padmaja, D. Physiological and biochemical traits of sesame (Sesamum indicum L.) varieties under rainfed conditions. Int. J. Chem. Stud. 2020, 8, 2277-2281. [CrossRef]

6. Dossa, K.; Mmadi, M.A.; Zhou, R.; Zhou, Q.; Yang, M.; Cisse, N.; Diouf, D.; Wang, L.; Zhang, X. The contrasting response to drought and waterlogging is underpinned by divergent DNA methylation programs associated with gene expression in sesame. Plant Sci. 2018, 277, 207-217.

7. Wang, L.; Li, D.; Zhang, Y.; Gao, Y.; Yu, J.; Wei, X.; Zhang, X. Tolerant and susceptible sesame genotypes reveal waterlogging stress response patterns. PLoS ONE 2016, 11, e0149912. [CrossRef] [PubMed] 
8. Pan, J.; Sharif, R.; Xu, X.; Chen, X. Mechanisms of waterlogging tolerance in plants: Research progress and prospects. Front. Plant. Sci. 2020, 11, 627331. [CrossRef]

9. Cortezi, D.G.; Colli, S. Effect of flooding and application of plant growth regulators on sprouting of Guazuma ulmifolia (Malvaceae) and Sesbania virgata (Fabaceae). Rev. Bras. Bot. 2011, 34, 423-430. [CrossRef]

10. Jackson, M.; Colmer, T. Response and adaptation by plants to flooding stress. Ann. Bot. 2005, 96, 501-505. [CrossRef] [PubMed]

11. Sachs, M.M.; Freeling, M.; Okimoto, R. The anaerobic proteins of maize. Cell 1980, 20, 761-767. [CrossRef]

12. Grassini, P.; Indaco, G.V.; Pereira, M.L.; Hall, A.J.; Trápani, N. Responses to short-term waterlogging during grain filling in sunflower. Field Crop. Res. 2007, 101, 352-363. [CrossRef]

13. Irfan, M.; Hayat, S.; Hayat, Q.; Afroz, S.; Ahmad, A. Physiological and biochemical changes in plants under waterlogging. Protoplasma 2010, 241, 3-17. [CrossRef]

14. Chugh, V.; Gupta, A.K.; Grewal, M.S.; Kaur, N. Response of antioxidative and ethanolic fermentation enzymes in maize seedlings of tolerant and sensitive genotypes under short term waterlogging. Indian J. Exp. Biol. 2012, 50, 577-582.

15. Neira, J.; Ortiz, M.; Morales, L.; Acevedo, E. Oxygen diffusion in soils: Understanding the factors and processes needed for modeling. Chil. J. Agric. Res. 2015, 75, 35-44. [CrossRef]

16. Boru, G.; Vantoai, T.; Alves, J.; Hua, D.; Knee, M. Responses of soybean to oxygen deficiency and elevated root-zone carbon dioxide concentration. Ann. Bot. 2003, 91, 447-453. [CrossRef] [PubMed]

17. Fujita, S.; Noguchi, K.; Tange, T. Different waterlogging depths affect spatial distribution of fine root growth for Pinus thunbergii seedlings. Front. Plant. Sci. 2021, 12, 386. [CrossRef] [PubMed]

18. Khanthavong, P.; Yabuta, S.; Asai, H.; Hossain, M.; Akagi, I.; Sakagami, J.-I. Root response to soil water status via interaction of crop genotype and environment. Agronomy 2021, 11, 708. [CrossRef]

19. Khabaz-Saberi, H.; Setter, T.; Waters, I. Waterlogging induces high to toxic concentrations of iron, aluminum, and manganese in wheat varieties on acidic soil. J. Plant. Nutr. 2006, 29, 899-911. [CrossRef]

20. Sreeharsha, R.V.; Sekhar, K.M.; Reddy, A.R. Delayed flowering is associated with lack of photosynthetic acclimation in Pigeon pea (Cajanus cajan L.) grown under elevated $\mathrm{CO}_{2}$. Plant. Sci. 2015, 231, 82-93. [CrossRef] [PubMed]

21. Desoky, E.-S.M.; Mansour, E.; El-Sobky, E.-S.E.; Abdul-Hamid, M.I.; Taha, T.F.; Elakkad, H.A.; Arnaout, S.M.; Eid, R.S.; El-Tarabily, K.A.; Yasin, M.A. Physio-biochemical and agronomic responses of faba beans to exogenously applied nano-silicon under drought stress conditions. Front. Plant Sci. 2021, 12, 637783. [CrossRef]

22. Mansour, E.; Desoky, E.M.; Ali, M.M.A.; Abdul-Hamid, M.I.; Ullah, H.; Attia, A.; Datta, A. Identifying drought-tolerant genotypes of faba bean and their agro-physiological responses to different water regimes in an arid Mediterranean environment. Agric. Water Manag. 2021, 247, 106754. [CrossRef]

23. Mansour, E.; Moustafa, E.S.; Desoky, E.-S.M.; Ali, M.; Yasin, M.A.; Attia, A.; Alsuhaibani, N.; Tahir, M.U.; El-Hendawy, S. Multidimensional evaluation for detecting salt tolerance of bread wheat genotypes under actual saline field growing conditions. Plants 2020, 9, 1324. [CrossRef]

24. Desoky, E.-S.M.; Elrys, A.S.; Mansour, E.; Eid, R.S.; Selem, E.; Rady, M.M.; Ali, E.F.; Mersal, G.A.; Semida, W.M. Application of biostimulants promotes growth and productivity by fortifying the antioxidant machinery and suppressing oxidative stress in faba bean under various abiotic stresses. Sci. Hortic. 2021, 288, 110340. [CrossRef]

25. Desoky, E.-S.M.; Merwad, A.-R.; Abo El-Maati, M.F.; Mansour, E.; Arnaout, S.M.; Awad, M.F.; Ramadan, M.F.; Ibrahim, S.A. Physiological and biochemical mechanisms of exogenously applied selenium for alleviating destructive impacts induced by salinity stress in bread wheat. Agronomy 2021, 11, 926. [CrossRef]

26. Anee, T.I.; Nahar, K.; Rahman, A.; Mahmud, J.A.; Bhuiyan, T.F.; Alam, M.U.; Fujita, M.; Hasanuzzaman, M. Oxidative damage and antioxidant defense in Sesamum indicum after different waterlogging durations. Plants 2019, 8, 196. [CrossRef] [PubMed]

27. Desoky, E.-S.M.; Mansour, E.; Ali, M.; Yasin, M.A.; Abdul-Hamid, M.I.; Rady, M.M.; Ali, E.F. Exogenously used 24-epibrassinolide promotes drought tolerance in maize hybrids by improving plant and water productivity in an arid environment. Plants 2021, 10, 354. [CrossRef] [PubMed]

28. Desoky, E.-S.M.; Mansour, E.; Yasin, M.A.; El Sobky, E.-S.E.; Rady, M.M. Improvement of drought tolerance in five different cultivars of Vicia faba with foliar application of ascorbic acid or silicon. Span. J. Agric. Res. 2020, 18, 16. [CrossRef]

29. Dumanović, J.; Nepovimova, E.; Natić, M.; Kuča, K.; Jaćević, V. The significance of reactive oxygen species and antioxidant defense system in plants: A concise overview. Front. Plant. Sci. 2020, 11, 552969. [CrossRef] [PubMed]

30. Sairam, R.; Kumutha, D.; Ezhilmathi, K.; Deshmukh, P.; Srivastava, G. Physiology and biochemistry of waterlogging tolerance in plants. Biol. Plant. 2008, 52, 401-412. [CrossRef]

31. Bin, T.; Xu, S.-Z.; Zou, X.-L.; Zheng, Y.-L.; Qiu, F.-Z. Changes of antioxidative enzymes and lipid peroxidation in leaves and roots of waterlogging-tolerant and waterlogging-sensitive maize genotypes at seedling stage. Agric. Sci. China 2010, 9, 651-661.

32. Jaiswal, A.; Srivastava, J. Changes in reactive oxygen scavenging systems and protein profiles in maize roots in response to nitric oxide under waterlogging stress. Indian J. Biochem. Biophys. 2018, 55, 26-33.

33. Wheaton, E.; Kulshreshtha, S. Environmental sustainability of agriculture stressed by changing extremes of drought and excess moisture: A conceptual review. Sustainability 2017, 9, 970. [CrossRef]

34. Gracia, M.; Mansour, E.; Casas, A.; Lasa, J.; Medina, B.; Cano, J.L.M.; Moralejo, M.; López, A.; Fuster, P.L.; Escribano, J. Progress in the Spanish national barley breeding program. Span. J. Agric. Res. 2012, 10, 741-751. [CrossRef] 
35. Abaza, G.M.S.M.; Awaad, H.A.; Attia, Z.M.; Abdel-lateif, K.S.; Gomaa, M.A.; Abaza, S.M.S.M.; Mansour, E. Inducing potential mutants in bread wheat using different doses of certain physical and chemical mutagens. Plant. Breed. Biotechnol. 2020, 8 , 252-264. [CrossRef]

36. Kamara, M.M.; Ghazy, N.A.; Mansour, E.; Elsharkawy, M.M.; Kheir, A.; Ibrahim, K.M. Molecular genetic diversity and line× tester analysis for resistance to late wilt disease and grain yield in maize. Agronomy 2021, 11, 898. [CrossRef]

37. Wang, X.; Deng, Z.; Zhang, W.; Meng, Z.; Chang, X.; Lv, M. Effect of waterlogging duration at different growth stages on the growth, yield and quality of cotton. PLoS ONE 2017, 12, e0169029. [CrossRef]

38. Arnon, D.I. Copper enzymes in isolated chloroplasts. Polyphenoloxidase in Beta vulgaris. Plant Physiol. 1949, $24,1-15$. [CrossRef] [PubMed]

39. Bates, L.S.; Waldren, R.P.; Teare, I. Rapid determination of free proline for water-stress studies. Plant Soil 1973, 39, 205-207. [CrossRef]

40. Hossain, M.S.; ElSayed, A.I.; Moore, M.; Dietz, K.-J. Redox and reactive oxygen species network in acclimation for salinity tolerance in sugar beet. J. Exp. Bot. 2017, 68, 1283-1298. [CrossRef]

41. Hemeda, H.; Klein, B. Effects of naturally occurring antioxidants on peroxidase activity of vegetable extracts. J. Food Sci. 1990, 55, 184-185. [CrossRef]

42. Csiszár, J.; Lantos, E.; Tari, I.; Madosa, E.; Wodala, B.; Vashegyi, Á.; Horváth, F.; Pécsváradi, A.; Szabó, M.; Bartha, B. Antioxidant enzyme activities in Allium species and their cultivars under water stress. Plant Soil Environ. 2007, 53, 517. [CrossRef]

43. Jia, W.; Ma, M.; Chen, J.; Wu, S. Plant morphological, physiological and anatomical adaption to flooding stress and the underlying molecular mechanisms. Int. J. Mol. Sci. 2021, 22, 1088. [CrossRef] [PubMed]

44. Morales-Olmedo, M.; Ortiz, M.; Sellés, G. Effects of transient soil waterlogging and its importance for rootstock selection. Chil. J. Agric. Res. 2015, 75, 45-56. [CrossRef]

45. Tabari, H. Climate change impact on flood and extreme precipitation increases with water availability. Sci. Rep. 2020, 10, 1-10. [CrossRef] [PubMed]

46. Attia, A.; El-Hendawy, S.; Al-Suhaibani, N.; Tahir, M.U.; Mubushar, M.; dos Santos Vianna, M.; Ullah, H.; Mansour, E.; Datta, A. Sensitivity of the DSSAT model in simulating maize yield and soil carbon dynamics in arid Mediterranean climate: Effect of soil, genotype and crop management. Field Crop. Res. 2021, 260, 107981. [CrossRef]

47. Zhou, M. Improvement of plant waterlogging tolerance. In Waterlogging Signalling and Tolerance in Plants; Springer: Berlin/Heidelberg, Germany, 2010; pp. 267-285.

48. Parelle, J.; Roudaut, J.-P.; Ducrey, M. Light acclimation and photosynthetic response of beech (Fagus sylvatica L.) saplings under artificial shading or natural Mediterranean conditions. Ann. For. Sci. 2006, 63, 257-266. [CrossRef]

49. Perez-Ramos, I.M.; Maranon, T. Effects of waterlogging on seed germination of three Mediterranean oak species: Ecological implications. Acta Oecol. 2009, 35, 422-428. [CrossRef]

50. Mensah, J.; Obadoni, B.; Eruotor, P.; Onome-Irieguna, F. Simulated flooding and drought effects on germination, growth, and yield parameters of sesame (Sesamum indicum L.). Afr. J. Biotechnol. 2006, 5, 1249-1253.

51. Ezin, V.; Pena, R.D.L.; Ahanchede, A. Flooding tolerance of tomato genotypes during vegetative and reproductive stages. Braz. J. Plant. Physiol. 2010, 22, 131-142. [CrossRef]

52. Palta, J.; Ganjeali, A.; Turner, N.; Siddique, K. Effects of transient subsurface waterlogging on root growth, plant biomass and yield of chickpea. Agric. Water Manag. 2010, 97, 1469-1476. [CrossRef]

53. Parent, C.; Capelli, N.; Berger, A.; Crèvecoeur, M.; Dat, J.F. An overview of plant responses to soil waterlogging. Plant Stress 2008, 2, 20-27.

54. Zaman, M.S.U.; Malik, A.I.; Kaur, P.; Ribalta, F.M.; Erskine, W. Waterlogging tolerance at germination in field pea: Variability, genetic control, and indirect selection. Front. Plant Sci. 2019, 10, 953. [CrossRef] [PubMed]

55. Subbaiah, C.C.; Sachs, M.M. Altered patterns of sucrose synthase phosphorylation and localization precede callose induction and root tip death in anoxic maize seedlings. Plant Physiol. 2001, 125, 585-594. [CrossRef]

56. Visser, E.; Voesenek, L.; Vartapetian, B.; Jackson, M. Flooding and plant growth. Ann. Bot. 2003, 91, 107-109. [CrossRef]

57. Wang, R.; He, P.; Shao, L.; Zhang, B.; Li, G. Responses of antioxidation system of Cynodon dactylon to recirculated landfill leachate irrigation. J. Appl. Ecol. 2005, 16, 933-938.

58. Hossain, Z.; López-Climent, M.F.; Arbona, V.; Pérez-Clemente, R.M.; Gómez-Cadenas, A. Modulation of the antioxidant system in citrus under waterlogging and subsequent drainage. J. Plant Physiol. 2009, 166, 1391-1404. [CrossRef]

59. Wei, W.; Li, D.; Wang, L.; Ding, X.; Zhang, Y.; Gao, Y.; Zhang, X. Morpho-anatomical and physiological responses to waterlogging of sesame (Sesamum indicum L.). Plant Sci. 2013, 208, 102-111. [CrossRef] [PubMed]

60. Damanik, R.I.; Maziah, M.; Ismail, M.R.; Ahmad, S. Responses of the antioxidative enzymes in Malaysian rice (Oryza sativa L.) cultivars under submergence condition. Acta Physiol. Plant. 2010, 32, 739-747. [CrossRef]

61. Xu, F.-y.; Wang, X.-l.; Wu, Q.-x.; Zhang, X.-r.; Wang, L.-h. Physiological responses differences of different genotype sesames to flooding stress. Adv. J. Food Sci. Technol. 2012, 4, 352-356.

62. Steffens, B.; Kovalev, A.; Gorb, S.N.; Sauter, M. Emerging roots alter epidermal cell fate through mechanical and reactive oxygen species signaling. Plant Cell 2012, 24, 3296-3306. [CrossRef] [PubMed] 
63. El-Sanatawy, A.M.; El-Kholy, A.S.; Ali, M.; Awad, M.F.; Mansour, E. Maize seedling establishment, grain yield and crop water productivity response to seed priming and irrigation management in a Mediterranean arid environment. Agronomy 2021, 11, 756. [CrossRef]

64. Moustafa, E.S.; El-Sobky, E.-S.E.; Farag, H.I.; Yasin, M.A.; Attia, A.; Rady, M.O.; Awad, M.F.; Mansour, E. Sowing date and genotype influence on yield and quality of dual-purpose barley in a salt-affected arid region. Agronomy 2021, 11, 717. [CrossRef]

65. Moustafa, E.S.; Ali, M.; Kamara, M.M.; Awad, M.F.; Hassanin, A.A.; Mansour, E. Field screening of wheat advanced lines for salinity tolerance. Agronomy 2021, 11, 281. [CrossRef]

66. El-Sanatawy, A.M.; Ash-Shormillesy, S.M.; Qabil, N.; Awad, M.F.; Mansour, E. Seed halo-priming improves seedling vigor, grain yield, and water use efficiency of maize under varying irrigation regimes. Water 2021, 13, 2115. [CrossRef] 